\title{
Wildlife conservation in the southern Sudan
}

\author{
Sir Christopher Lever
}

The wildlife of southern Sudan is profuse and diverse but its potential for tourism is scarcely developed. Its conservation is hampered by fuel shortages and the inaccessible nature of the country, and heavily armed poachers have slaughtered large numbers of elephants for ivory. The author, who visited the country in 1982, reports on the conservation work that is being carried out despite the problems.

From 1955 to 1972 the people of the southern Sudan were involved in a fierce conflict with their compatriots in the north. During this period three other East African countries-Tanzania, Uganda and finally Kenya - won their independence and began the formation of a series of national parks and game reserves* which, largely through the medium of television, have become world famous and have generated both a flourishing tourist industry and an influx of foreign funds for conservation purposes. The southern Sudanwhich apart from Tanzania (and Uganda before the bloody reign of Idi Amin) has a greater profusion of wildlife than any other country in Africa and is almost unequalled for its variety of species-has remained undeveloped and largely neglected.

*Broadly speaking the difference between a national park and a game reserve is that in the former total protection of the fauna and flora is the primary objective and human activities are precluded, while in the latter, although nature conservation remains of paramount importance, human utilisation of the land, such as the grazing of cattle and goats, may be permitted.
The region's topography is both its wildlife's most valuable ally and also the principal impediment to its conservation. Much of the area is a vast, unbroken floodplain which, between May and December, is either inundated or a morass of mud, rendering it virtually impenetrable. While this has effectively prevented detrimental human intrusion it has also largely inhibited active conservation measures. A perpetual shortage of fuel has added to the difficulties of transportation. Another obstacle to the development of the southern Sudan-the shortage of foreign currency-may, however, eventually be removed by the exportation of oil, which has been discovered in viable amounts in the Nile floodplain.

During a recent visit to Juba -the principal town of the southern Sudan about $125 \mathrm{~km}$ north of the Ugandan border - I was able to see at first hand the efforts being made to conserve the wildlife of the region.

The Wildlife Department in Juba, which operates under the provision of the Wildlife Conservation and Parks Act of 1975, receives invaluable foreign assistance in its conservation ventures. Of these the earliest was the Sudan Wildlife Conservation Project, which has been financially supported since 1976 by the Frankfurt Zoological Society, with logistical assistance from German Technical Aid. A more recent development has been the formation-again with German financial support-of a Department of Wildlife in the College of Natural Resources and Environmental Science at Juba University: this is geared to the production of graduates qualified both as fieldworkers and researchers and in the education of their fellow-countrymen in the importance of wildlife conservation. The African Wildlife Oryx Vol 17 No 4 
Leadership Foundation has also recently begun a programme of education in conservation for the people of the region.

The New York Zoological Society is providing valuable aid in the small forested Bangangai Game Reserve near the border with Zaire, which has a wide variety of woodland primates and a considerable population of the elusive and largely nocturnal bongo Tragelaphus euryceros, and in the Boma National Park, north-west of the Boma plateau on the Ethiopian border, where research is being conducted into the population dynamics and migration of the white-eared kob Kobus kob leucotis, which probably numbers in excess of one million.

Elsewhere the Italian government has financed and conducted an ecological survey of the Southern National Park-the largest in the region-while on the west bank of the White Nile attempts are being made to enlarge the small Shambe Game Reserve and to raise it to the status of a national park, and at the same time to study, under the auspices of the New York Zoological Society, the Species Survival Commission of the International Union for the Conservation of Nature, and the World Wildlife Fund, the northern sub-species of the white rhinoceros Ceratotherium simum.

The most important current development project in the southern Sudan is the construction of the Jonglei Canal (scheduled to run from that town on the Nile in the south past Kongor, Duk Faiwil, Duk Fadiat and Ayod to rejoin the Nile in the vicinity of Taufikia in the north) which will bypass to the east of the Nile the notorious and virtually impassable Sudd. With financial backing from the European Development Fund, a group of scientists under the leadership of Dr Stephen Cobb (1981), Director of the Jonglei Research Project, is attempting to discover some of the potential ecological consequences-both beneficial and detrimental-which are likely to result from the canal's construction: they are investigating the possible effects on the fertility of pasturage; on the fecundity, diseases and seasonal nomadic movements of the cattle and goats of the Dinka, Nuer and Shilluck tribesmen; on the region's water resources and on the area's wildlife, with particular emphasis on the population dynamics and migrations of the tiang Damaliscus lunatus tiang Conservation in southern Sudan

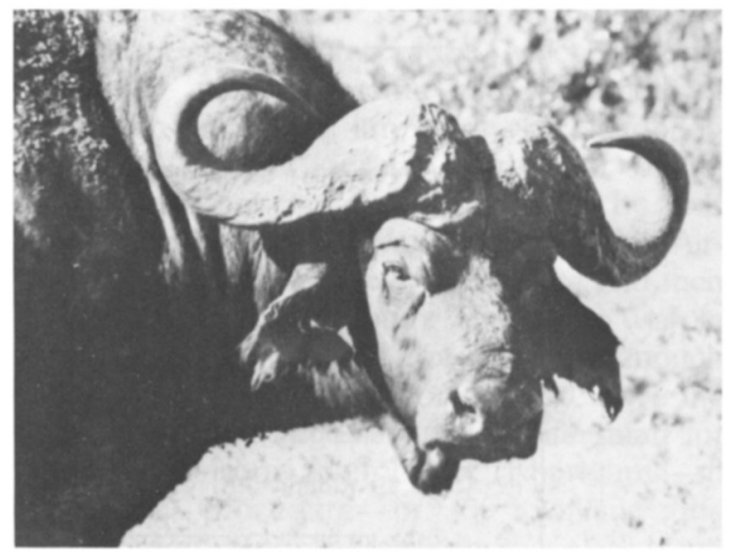

African buffalo (Sir Christopher Lever).

(a race of the tsessebi or topi) of which there are some 500,000 in the Jonglei, and the largely aquatic Nile lechwe Kobus megaceros, which is endemic to the floodplains of the southern Sudan.

While in Juba I made aerial surveys of the Boma plateau and the Pibor river-a tributary of the Nile - in the national park, some 300 or so $\mathrm{km}$ to the north-east and, on a flight to Wau $500 \mathrm{~km}$ north-west in the province of Bahr-el-Ghazal, of the Southern National Park and the Numatinna Game Reserve. In all three areas large numbers of game were visible.

I was also able to visit the Badingilu Game Reserve near the Badigero swamp, $75 \mathrm{~km}$ northeast of Juba; here, among the more abundant larger mammals are common zebra Equus burchelli, African buffalo Synceros cafer, reticulated giraffe Giraffa camelopardalis reticulata, Jackson's hartebeest Alcelaphus buselaphus jacksoni, bohar reedbuck Redunca redunca, giant eland Tragelaphus derbianus gigas, warthogs Phacochoerus aethiopicus and kob. In the swamps the commonest birds include marabou storks Leptoptilos crumeniferus, yellow-billed storks Ibis ibis, little egrets Egretta garzetta, cattle egrets Bubulcus ibis, and knob-billed geese Sarkidiomis melanotos; grasshopper buzzards Butastur rufipennis are the most abundant raptors and griffon vultures Gyps ruppellii the commonest scavengers. 


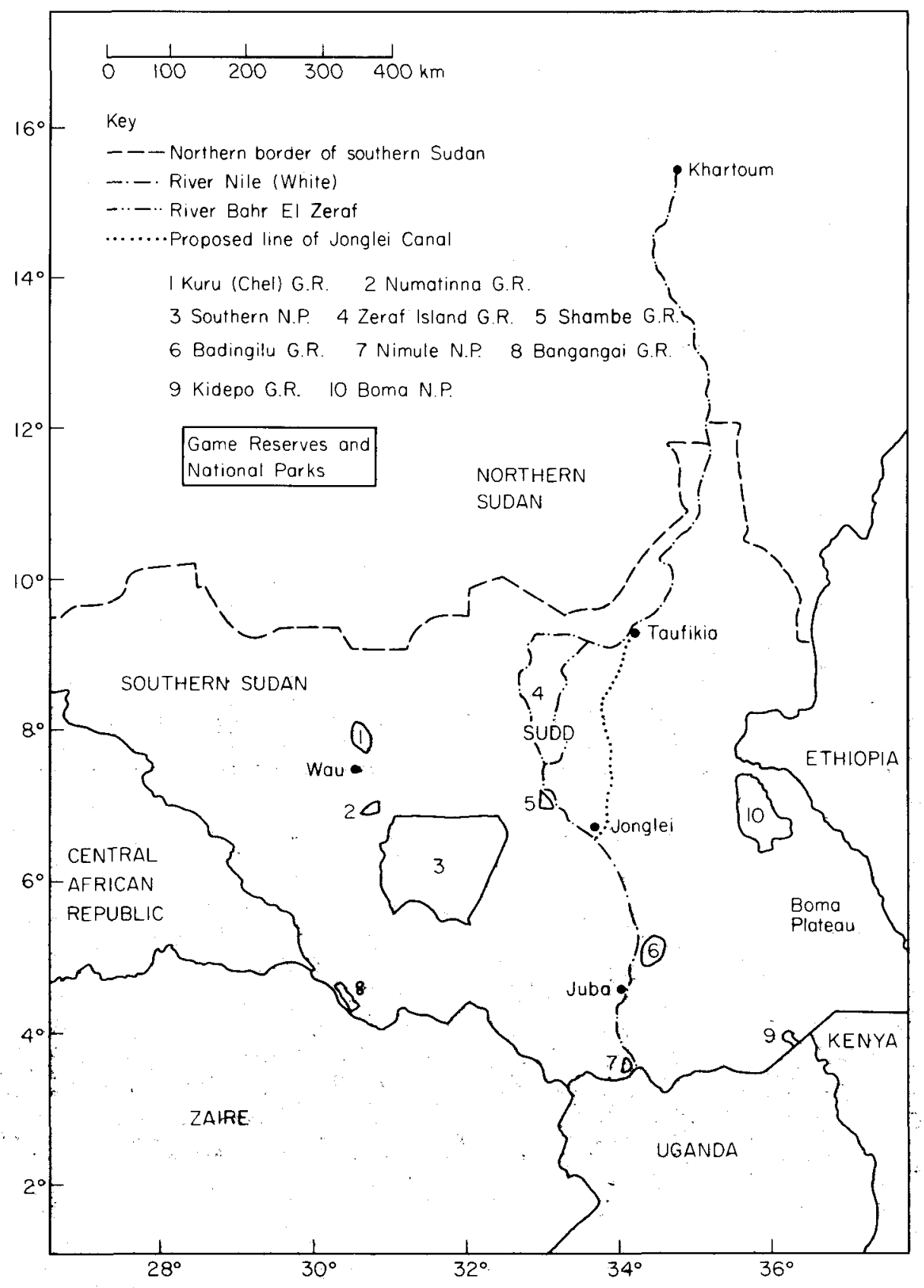

One of the main problems to be overcome in the development of wildlife conservation in the southern Sudan is, as elsewhere, the sometimes uneasy relationship between conservationists and local tribesmen, whose traditional rights to grazing, hunting and settlement cannot be ignored. As Dr Cobb points out, to the Dinka of Jonglei and the Murle of Boma the successful hunting of tiang and kob respectively provides a valuable source of protein. If wildlife conservation in the southern Sudan is to succeed, ways and means must be found of maintaining for the 192 Oryx Vol 17 No 4 
human inhabitants their age-old rights; only thus will conservationists secure their willing cooperation, without which little can be achieved.

A recent report by Earthscan (Grainger, 1983), produced with financial support from the United Nations Environment Programme, draws attention to another potential problem of the Sahel region as a whole. Increasing desertification could well lead to a similar period of drought such as that which between 1968 and 1973 was responsible for the deaths of up to a quarter of a million people and some 3500,000 head of cattle. At the present time domestic herds are approaching pre1968 levels, and are seriously over-grazing the sparse vegetation, where the rate of tree-felling, to meet the demands of a population that is increasing by around 2.5 per cent a year, exceeds that of regeneration. This could result in both the mass starvation of people, stock and game, and also in increasing intrusion by the human population into game reserves and national parks. The situation clearly requires careful monitoring.

Another difficult problem in the southern Sudan is, as elsewhere, the perennial one of poaching. While in Badingilu we came on a party of tribesmen who had illegally killed an eland cow; this kind of subsistence poaching could be prevented by greater freedom to hunt outside the reserves. A more dramatic example of the local tribesmen's shortage of protein was provided by the two game-wardens who accompanied us and risked their lives to drive a lioness from her prey-a young warthog-which she had killed one evening within $50 \mathrm{~m}$ of our camp.

Less easy to cope with are the large and heavily armed gangs of commercial poachers from the province of Darfur in the north who, mounted on camels, have been slaughtering huge numbers of elephants for their ivory in Bahr-el-Ghazal in the south, where there have been several serious skirmishes with ill-equipped government forces. A few years ago some white rhinoceroses were introduced to Meru Game Reserve in northern Kenya, where they were subsequently killedallegedly by Somali poachers-for their homs, which then found a ready market for making into dagger-handles in the Yemen; unless care is taken the same fate could well befall the white rhinoceroses of Shambe.

Conservation in southem Sudan
At the moment the possibilities for visiting the southern Sudan are few; Juba, which has only one small hotel, lies some $1200 \mathrm{~km}$ south of Khartoum and $900 \mathrm{~km}$ north of Nairobi in Kenya-a difficult journey by road of several days from either capital. Transportation by air is erratic and uncertain-my flight by Sudan Airways from Nairobi took off a day late and then overflew Juba to Khartoum. Those who wish to visit the region, but are not fortunate enough to have someone with whom to stay, have the option of either organising a private safari for themselves from Nairobi or Khartoum-an expensive procedure-or of awaiting the development of tourist facilities; these will inevitably take some time to materialise but, providing present conservation policies continue, visitors should eventually be rewarded by the sight of some of the largest concentrations of animals in the whole of Africa.

\section{Acknowledgment}

For their hospitality in Juba I should like to thank Dr and Mrs R.H. Ansell.

\section{References}

Cobb, S. 1981. Wildlife in southern Sudan. Swara 4 (5), $28-31$

Grainger, A. 1983. Desertification. 94 pp. Earthscan.

Sir Christopher Lever, Bt. Newell House. Winkfield, Windsor, Berkshire SL4 4SE, UK.

\section{Tailpiece}

The very first activities of the Society were concerned with reserves in the southern Sudan. In fact the Society was formed after a delegation of eminent naturalists, diplomats and parliamentarians had delivered a memorandum to the Earl of Cromer, which led to the abandonment of a proposal to abolish the Game Reserve between the Blue and White Nile. The full texts of the Sudan Gazette dealing with Game ordinances were published in the Journal of the Society for the Preservation of the Wild Fauna of the Empire (as Oryx was then known). Ever since then the ffPS has published articles and updates on wildlife in the Sudan, and the Society's Honorary Secretary, David Jones of London Zoo, has been involved as consultant on the Jonglei Canal project. 